\title{
FRAY RAMÓN VALVIDARES Y LONGO (1769-1826), ESCRITOR POLÍTICO ANTIMODERNO ${ }^{1}$
}

\author{
Joaquín Álvarez BarRIENTOS \\ CSIC (Madrid)
}

\section{BREVE BIOGRAFÍA}

El nombre de este fraile jerónimo es relativamente conocido entre quienes se dedican a la literatura de la Guerra de la Independencia, y debe ese conocimiento, sobre todo, a su labor como poeta. Pero es responsable de una variada producción, en los géneros más dispares, salvo el dramático, toda ella dirigida a combatir la invasión y el contagio franceses, ya en su vertiente política o ideológica, el liberalismo -pues lo ve como causa-efecto-, ya en su faceta militar. Ambos aspectos ordenan una estrategia combativa basada en dar continuidad a la imagen del enemigo, que se identificaba con lo francés.

Fray Ramón nació en Sevilla el 3 de noviembre de 1769 y fue recibido como novicio en Bornos, provincia de Cádiz, el 7 de marzo de 1787. Profesó en el monasterio de Santa María del Rosario el 9 de marzo de 1788, de donde se fugó, junto con otro compañero, al año siguiente, el 3 de diciembre de 1789. Aproximadamente desde 1800 se repiten las quejas porque pasa más tiempo fuera que dentro del monasterio, a menudo sin justificación y otras veces «con el achaque de sus publicaciones». Hasta

1. Este trabajo adelanta algunos aspectos de la introducción a la novela de Valvidares, El liberal en Cádiz, o aventuras del abate Zamponi, que publicará la Diputación de Cádiz este año. En ella, con más detalle y detenimiento, se tocan los asuntos que aquí se tratan y otros, y en la misma se encuentran precisiones bibliográficas y de archivo. 
que en febrero de 1807 se considera ya excesivamente prolongada su ausencia y se acuerda usar «de todo rigor» para que vuelva.

El Archivo Histórico Nacional, de donde se extraen estos datos, guarda otras noticias relacionadas con él, por las que se sabe que en Sevilla y en 1814 estaba en trance de montar una imprenta, aunque no parece que regentara ninguna. Llegó a ser prior del monasterio de Écija y en 1815 intentó ser nombrado Predicador del rey, lo que no consiguió, aunque sí otros empleos y dignidades eclesiásticos, como examinador sinodal, calificador de la Inquisición, etc. También perteneció a la Real Academia sevillana de Buenas Letras (Aguilar Piñal, 2001). Conoció la exclaustración en 1809, se vio obligado a huir a Portugal ante el avance de las fuerzas francesas y, más tarde, al comienzo del Trienio Liberal, fue encarcelado durante un breve periodo. Murió el 23 de diciembre de 1826.

\section{ACERCA DE SU OBRA: LITERATURA DE GUERRA}

La primera publicación suya de que se tiene noticia es la Descripción poética. La terrible inundación que molestó a Sevilla en los días 26, 27 y principalmente en la desgraciada noche del 28 de diciembre del año de 1796. Aparecida al año siguiente, le valió varias críticas por sus inexactitudes, «nacidas de malos informes que se tomaron para su desempeño», según Justino Matute (1887), pero está bien escrita. Va dedicada, iniciando su costumbre de ofrecer a algún poderoso todas sus obras (y en especial a los miembros de la familia real) a doña Ramona Godoy. Comienza también su costumbre de poner notas a sus composiciones. A otra desgracia famosa, a la del terremoto de 1755, dedica un sermón en 1807, y en 1808 publica La Victoria, oda en honor del General Castaños, por la batalla ganada a las tropas francesas sobre los campos de Bailén el día 20 de julio.

Aquel mismo año dio a las prensas un texto que entra de lleno en la literatura contra Napoleón. Se llama El desengaño. Discurso histórico, político y legal sobre la falsa política de Napoleón I. Aunque «el desengaño» pueda hacer pensar en un escrito barroco, se trata de un panfleto contra la invasión francesa, bien informado y escrito con la buena pluma de que a menudo hace gala el autor. Un panfleto que se lee bien, como otras obras suyas, y que funde la arenga propagandística y agitadora, con la retórica más reposada del discurso político. Como indica en el texto, se vale de datos y argumentos extraídos de la historia, el derecho y la política para mostrar la injusticia y la traición cometida por Napoleón.

La argumentación quiere captar a los españoles, pero también a los franceses que sufren bajo el dictador corso, a los europeos y, por último, 
a los andaluces. La interpretación regional, local, de la patria prevalece en El desengaño, en el que se hacen varias alabanzas territoriales de interés, en tanto que muestras de arengas basadas en el amor a la patria chica, aunque no se olvide de «España, esa nación brillante y generosa» (1808b: 3 ), que está destinada a salvar a las demás naciones europeas. Tampoco olvida Valvidares trazar el retrato en negro del dictador, aunque le interesa más insistir en la resistencia que se da dentro de Francia, donde no se ha respetado la propiedad privada, en lo que insistía Burke (2003) al referirse a los males de la Revolución, ni se da la estabilidad necesaria para prosperar (1808b: 5-7).

Tras estos argumentos habituales, entra a rechazar la invasión, desde el punto de vista del Derecho, la actuación de Napoleón y el trato dado a la monarquía española, y así plantea la ilegalidad de la invasión desde el derecho natural, el divino, el civil, el de gentes, el de tradición, el de propiedad, el de conquista, el de costumbre, el municipal (1808b: 14-16), para concluir:

Ilegal y nula, porque nuestros reyes no son árbitros del trono donde los colocó la nación; ni tampoco pueden variar el orden que les prescribe nuestro derecho en la sucesión de la monarquía (1808b: 16).

Ilegal y nula, en fin, porque cuando hubiese alguna razón para dudar sobre el derecho de pertenencia, solo tocaba a la nación reunida en Cortes generales la resolución de esta duda (1808b: 17-18).

El grueso de la reivindicación se basa en la legalidad del régimen que ha sido agredido, en que la «nación española» había reconocido por rey a Carlos IV y luego a Fernando VII, al que se había jurado como Príncipe de Asturias en las Cortes generales de 1789, y en que, por tanto, la acción de Napoleón es ilegal.

La arenga, la adulación a veces a los españoles, remite a las antiguas laudes Hispaniae, pero tiene la peculiaridad de que son laudes Hispaniae de carácter bélico. Como en otras ocasiones, el autor actualiza y politiza modelos anteriores y les saca buen partido, porque nuestra geografía, plácida, amable y generosa, bajo su mirada se convierte en espacio inexpugnable. El locus amoenus que ha sabido acoger a los que venían con buenas intenciones, se vuelve agreste contra aquellos que lo quieren dominar por la fuerza:

No era necesario más que el tirano Emperador hubiese examinado con atención el mapa geográfico de nuestra península, para no dar sobre ella un golpe tan contrario a sus ambiciosas ideas. Vería entonces allí los elevados muros de sus fronteras, 
los montes inaccesibles que la cercan, los innumerables castillos y plazas que la defienden, los anchos y caudalosos ríos que la dividen, las intransitables lagunas y arroyos que la bañan, las escarpadas sierras que la amparan, las grutas y cavernas que la favorecen, las estrechas gargantas que la escudan, los robustos puentes que la cortan y cubren, y las altas murallas y ciudades que la hacen inconquistable (1808b: 29- 30).

El desengaño es ejemplo de propaganda dirigida a todos, pero en especial a la retaguardia. Es uno de los muchos casos que se dieron de panfletos destinados a mantener altos el optimismo y la moral ante los enemigos, por eso se recuerdan acciones victoriosas o de las que sentirse orgullosos, como el levantamiento del 8 de mayo, que «ha fijado la época memorable» de la fidelidad sevillana (1808b: 32) y otros, en claro tono de agitador. Y, por lo mismo, se recuerda que los sacrificios tienen un sentido, a pesar del dolor, y este es que los españoles conserven «sus intereses, la Religión de sus Padres, la quietud de sus hogares, la unión amorosa de sus familias, la suave dominación de un Rey amado y el derecho sagrado de la independencia» (1808b: 41). Es decir, que se mantengan la tradición, los valores heredados y la continuidad de un mundo. Si esto se consigue, y es la conclusión del panfleto, la Religión ultrajada y la Patria zozobrante y asaltada bendecirán a los.

Con este panfleto, Valvidares se convierte en escritor y en escritor político, pues lo que hasta entonces había compuesto sólo eran piezas de ocasión. La Guerra le dio la oportunidad. Fue, además, un fácil versificador, como demuestran sus numerosos poemas y fábulas, publicados en periódicos y luego recogidos en libros. Así las Fábulas satíricas, políticas y morales sobre el estado actual de Europa, de 1811, por ejemplo, ofrecidas a Carlota Joaquina de Borbón, infanta de España y princesa del Brasil ${ }^{2}$. Aparecieron sin pie de imprenta, solo con la fecha, aunque seguramente fueran publicadas en Sevilla, como casi todo lo que hizo.

Estas fábulas, que son, obviamente, literatura de guerra, están inspiradas por «el amor a su patria» y van contra los franceses, pero también contra aquellos que se les acercan, que son «políticos egoístas» y «partidistas maliciosos». Frente a éstos sitúa a los verdaderos españoles, que mezclan «la pérfida sangre de sus invasores con la de sus hijos leales», y así hacen, en una alteración del valor de los símbolos, «brotar entre las mismas cadenas el árbol frondoso de su libertad», al paso que abren «el camino al heroísmo de otras naciones que gemían en la dura esclavitud»

2. Es posible que nos encontremos ante una de las primeras ocasiones en que un autor califica y titula sus fábulas como «políticas» (Freire, 1988: 304). 
(1811: s.p.). Tampoco duda Valvidares, aplicando la lógica de su punto de vista, en jugar y hacer suyos los símbolos de la libertad, cambiando sus referentes. Esta actitud de pérdida de miedo a los iconos del pensamiento liberal, muestra a un autor moderno ante el entorno en el que va a jugar sus cartas. No es mojigato, ni recalcitrante, ni apocalíptico, como los escritores de la reacción, cuyos caracteres estudió Javier Herrero (1988), y es capaz de utilizar el propio lenguaje y los referentes del «enemigo» para ofrecer su visión de las cosas, que es claramente nostálgica del pasado monárquico. A lo largo de las páginas siguientes se podrá ver esa faceta de su carácter y escritura que, a mi ver, lo distancia de los reaccionarios y hace de él una de esas figuras intermedias, que viven en conflicto con la modernidad de su época porque no la asumen absolutamente, ni la rechazan del todo, y porque, de ella, ven más los efectos negativos que los positivos.

Como se dirige a un público concreto y cree en la fuerza de la educación, explica por qué se sirve de las fábulas para realizar el análisis del estado en que se encuentra Europa, y lo hace, con la demasiada credulidad teórica que también tuvieron los ilustrados en los valores didácticos -lo que es ejemplo de asimilación desde el conservadurismo de ideas que habían sido progresistas, y de cómo, a pesar de los intentos por volver atrás, se estaba ya en un tiempo nuevo, que podía dar significados nuevos a conceptos antiguos.

Su compromiso político, didáctico y social con los defensores de la patria le lleva a este tipo de literatura y a poner «notas instructivas» a los versos. En este sentido, Ramón Valvidares tiene presentes, y como destinatarios finales, las generaciones futuras, a las que se dirige, en última instancia, desde unas composiciones que, aunque nacen de la urgencia y tienen como referente inmediato la guerra, pretenden (y presuponen) alcanzar una época en «que los venideros puedan formar una exacta idea de esta obra, aun cuando lleguen a olvidarse con el tiempo los hechos principales de nuestra historia que han dado margen a su publicación» (1811: 221). Así, pues, Fray Ramón deja las cosas bien atadas, en previsión de que su obra alcance la posteridad, para que su mensaje llegue a los «bravos españoles/ y amigos leales» que, también en el futuro, escucharán los «avisos/grandes e importantes» de sus versos (1811: 3). Porque ser español no cambia, y se es siempre y en todo momento y lugar del mismo modo.

En el plano de la literatura de carácter religioso, compuso bastantes sermones, aunque solo se encuentran el dedicado al terremoto de 1755 y el que en 1816 leyó en la catedral de Sevilla ante los dos cabildos y como Prior del monasterio de Écija, sobre Fernando III el Santo y la «feliz restauración y conquista hecha del yugo mahometano en el año de 1248». En 
realidad, el sermón tiene mucho de político e ideológico, y Fray Ramón aprovecha la glosa de las virtudes y acciones bélicas del santo monarca para justificar el mundo de valores que estaba siendo amenazado desde los tiempos de la Guerra de la Independencia, y así aprieta el argumento para demostrar lo necesario que es respetar a los eclesiásticos, venerar a los prelados y obedecer a la Iglesia. De 1819 es la Relación circunstanciada de las solemnes exequias con que la Ilustre y Noble Ciudad de Carmona honró la memoria de Nuestra Reina y Señora Doña María Isabel de Braganza, que se completa con una oración fúnebre.

Vista su producción de forma global, se percibe que se mueve en dos líneas que asientan un mismo mensaje: una, la religiosa, a base de sermones, paráfrasis bíblicas y reflexiones sobre la predicación, como seguramente en Retórica crítica del púlpito (que es obra que no encuentro); y otra, la política, con variadas manifestaciones, que van desde los mismos sermones y fábulas al poema épico, pasando por la novela y los escritos defensivos de los derechos de los frailes.

La Iberiada, quizá su trabajo más conocido junto con las fábulas, «poema épico sobre el sitio y heroica defensa de Zaragoza», se publicó en dos tomos en 1813, con segunda edición en 1825. Sigue como modelo la Eneida de Virgilio, aunque hay otras obras de similar carácter que están en su trasfondo. Se trata de doce cantos, más notas eruditas, que detallan la defensa de Zaragoza. Tuvo bastante eco en la prensa y tantos elogios recibió que situaban a su autor a la altura de Garcilaso, Ercilla «y demás poetas de nuestros buenos tiempos», como críticas.

Si las Fábulas se publicaron con urgencia, en papel de mala calidad y en tamaño dozavo; el poema épico apareció en cuarto, con buen papel y bien encuadernado. Las dos ediciones, de 1813 y 1825, estaban apoyadas por sendas largas listas de destacados suscriptores españoles, ingleses y portugueses, en las que figuran el duque de Wellington, el del Infantado, el de Frías, la condesa de Benavente, el de Maule, el de Noroña, el obispo de Sigüienza, el embajador británico, Pedro Cevallos, Martín de Garay, Juan Álvarez Guerra, el General Castaños, Cayetano Valdés, el encargado de negocios de Portugal, el arcediano de Medina, el de Segovia, Manuel de Lardizábal, Santiago Terri, Martínez de la Rosa, José Istúriz, Juan Antonio Llorente, Ángel de Saavedra, entre otros que en 1813 alcanzan el número de ciento sesenta y uno.

La lista de 1825 es aún más larga. Ciento sesenta y ocho en el primer tomo y doscientos veintiuno, en el segundo, confirman el buen momento del fraile y el deseo de muchos de colocar su nombre junto al del rey Fernando VII, que se suscribe con cuatro ejemplares y 1000 reales para ayuda de impresión. Además, se suman los infantes Carlos María, Francisco de Paula, 
don Sebastián y la infanta Princesa de Beira, cada uno por dos ejemplares y 320 reales de ayuda. A continuación, el Nuncio de Su Santidad, por dos ejemplares; el Ministro de Dinamarca, dos ejemplares; Jaime Créus, arzobispo de Tarragona, el Secretario de Cámara de la Nunciatura Apostólica, Don Juan Gualberto, Fiscal del Consejo de Indias, los Ministros de Estado y Hacienda, el conde de Vigo, el Seminario de Sigüenza, el General Castaños, el marqués de la Romana, el Comisario General de la Cruzada, José de Heredia, el obispo de Vich. El duque del Infantado, Francisco Mateo Calomarde, López Ballesteros, la condesa- duquesa de Benavente, el marqués de Ariza, el conde de Fernán- Núñez, el duque de Medinaceli, los embajadores de París, de las Dos Sicilias, de Lisboa, Turín, Viena, Rusia, Dresde, Países Bajos, Londres, Estados Unidos, Berlín, Nicolás Tap y Núñez, Juan José Mariátegui, Blas de Ostolaza, el barón de Maldá, entre otros.

El libro está dedicado en 1813 a Fernando VII, «y en su nombre a la Regencia de las Españas», y en 1825 «A Nuestro Católico Monarca el Señor don Fernando VII, rey de las Españas». Surge, como otras obras, en respuesta al concurso convocado por la Suprema Junta Central Gubernativa del Reino, según decreto expedido en el Real Alcázar de Sevilla el 9 de marzo de 1809, «para conmemorar tan gran proeza y sacrificio, que es ejemplo que admira a las naciones». Ante la importancia patriótica de la defensa zaragozana, no quiere Valvidares componer sólo una breve oda o un poema sucinto -como solicitaban las bases-, sino uno épico, en el que, entre otras cosas, demuestra la necesidad que las armas y las letras tienen de caminar juntas, pues si las primeras defienden y procuran héroes, las segundas son necesarias para dejar constancia de los hechos de esos héroes. Algo que le venía al pelo para escribir sobre los sitios de Zaragoza. En todo caso, y dado el momento histórico en que se encontraba, la alusión a las armas y las letras no es solo retórica, pues ya estaba claro para todos el importante papel del escritor como conformador y manipulador de la opinión pública. De modo que si había guerra y batalla con las armas, también la había con las plumas y las letras, como escribía El Conciso del 16 de enero de 1814.

Con su habitual consideración didáctica, además de los doce cantos poéticos, el libro se completa con abundantes notas eruditas, con una «Razón y prospecto de este poema» y un «Argumento histórico sobre La Iberiada», en el que narra el aspecto bélico de la cuestión, para que además se tenga ese relato «fidedigno» y no solo la recreación poética. El largo poema, como casi todo lo que escribió, se inserta en el grupo de escritos patrióticos, de defensa y exaltación de los valores nacionales. Relata las aventuras de Palafox, quien obedece a los dioses romanos que se le aparecen en los diferentes sueños que tiene y le dicen lo que debe hacer. Hay que resaltar el fuerte sentido del destino que tiene el héroe, que acepta desempeñar cuanto 
se le comenta cada vez que se vuelve a dormir. Ma Pilar Salas Yus (2007: 15) considera que el poema, por su argumento, recuerda La Ilíada de Homero, y señala que «esta poesía culta canta las mismas proezas, los mismos ideales y a los mismos héroes que la poesía popular, descalifica de igual manera a Napoleón y a los soldados franceses, ensalza la valentía, lealtad, piedad, honorabilidad de los aragoneses, pero cuida más el vocabulario utilizado y elabora más la versificación». Conviene también señalar que, por el tipo de libro, de género y de métrica, así como de imágenes y construcción del relato, el trabajo, aunque comparta ciertas similitudes, aspira a dirigirse a otro lector que no siempre tiene por qué coincidir con el de las Fábulas, o el de la literatura popular, y presupone, desde la perspectiva del autor, dotar a su obra de un horizonte más amplio y de consagración canónica, que no se piensa para manifestaciones literarias expuestas en otros géneros. En todo caso, la unicidad del mensaje que se lanza tanto a unos como a otros lectores, por diversos medios, pone de manifiesto la coherencia de estos emisores embarcados en la tarea de defender una moral y una forma de entender la patria, que debe ser mantenida por todos. Aunque en la elección de un género u otro haya también intencionalidad diferente.

La Iberiada conoció bastante éxito y alcanzó, como se ha visto, una segunda edición en plena Década Ominosa. Esta segunda edición y que el rey junto a otros destacados miembros de su familia favorecieran la reimpresión, dice mucho del favor con que contaba Fray Ramón, que había pasado grandes trabajos, persecuciones y prisión por defender la institución monárquica. También ha de ser consecuencia de la insistencia con que pedía se le reconocieran los servicios en favor de la Corona.

Pero la obra tiene ripios y tics propios de este tipo de trabajos y, con ironía, Leandro Fernández de Moratín los señaló en un apunte manuscrito y autógrafo que se conserva en la Biblioteca Nacional (ms. 12963/ 26). En él, que no es más que una cuartilla, resume con apretada letra el argumento de cada canto, y a continuación copia varios versos y frases de La Iberiada, sin ningún comentario. Pero el carácter del resumen y los fragmentos copiados dan por sí solos parte del tono del poema y, seguramente, su opinión sobre el mismo. Algunos de ellos son éstos: «corría la titilante sangre, los destrozados sesos, turbión polvoso, tremulante pavor, huyendo escapa, el invicto Renovales, y sin rodeo te digo que este es quien ventila el honor de la patria, ciudad añosa».

También la leyó Alcalá Galiano, que señala que fueron muchos quienes lo hicieron, a pesar de su desconfianza sobre sus capacidades poéticas: «El Padre Valvidares versificaba con gran facilidad y fluidez, pero sus versos carecen de animación y nervio, y de los grandes atributos que caracterizan a un poeta, no hay ninguno seguramente al que pueda aspirar» (1969: 108). 
Sin embargo, Alcalá Galiano incluía, aunque con críticas y reservas, a Fray Ramón en el panorama canónico que de la literatura española ofrecía en 1834 al público internacional desde la revista The Athenaeum.

Después del esfuerzo que debió de suponerle escribir y anotar el largo poema épico, en circunstancias como las aludidas, eligió un género en apariencia más ligero para su siguiente trabajo literario, la novela, y así compuso El liberal en Cádiz o aventuras del abate Zamponi (Ferraz Martínez, 1997). Fue publicada en Sevilla, en 1814, por la imprenta del Correo Político Mercantil, calle de Vizcaínos, a cargo de Manuel Valvidares, seguramente hermano del autor. Esta imprenta, de efímera vida, publicó siempre libros a favor del Trono y del Altar, como los del Filósofo Rancio. Aparece en momentos en que, a pesar de las críticas que los absolutistas hacen a la libertad de impresión, se sirven de ella para combatir el pensamiento liberal. Si se publicaron muchos textos favorables, muchos más fueron los que asentaban y defendían el pensamiento conservador. La campaña en defensa del orden de cosas atacado, que se acabará reinstaurando, fue mayor que la que llevaron a cabo los partidarios del nuevo orden e imaginario social.

El liberal en Cádiz es el relato de cómo se prepara al protagonista para ser liberal. Se trata de un joven de un pueblo sevillano que, como otros personajes de novelas anteriores, quiere salir de su lugar y ser algo distinto de lo que es y de aquello a lo que parece abocado. Aquí, el joven Perucho quiere ser liberal. Para conseguirlo, su padre paga a un abate, maestro en enseñar ese arte, para que le dé clases. Lo peculiar es que convertirse en liberal es algo similar a convertirse en caballero: hay que cumplir determinados requisitos y pasar ciertos ritos, que suponen la conversión del personaje en otro. Debe abandonar su nombre -de Perucho pasará a ser Zamponi-, ha de olvidar sus conocimientos anteriores, adquirir un hábito e indumentaria nuevos, que lo señalan como liberal, y, finalmente, soportar un rito de paso, mediante el cual Zamponi queda «armado liberal».

Aunque la escena se presenta como el no va más de la idiotez de los personajes, que quieren ser liberales (pues finalmente, hasta los padres y la hermana del protagonista tienen ese deseo), sus razonamientos, y en especial los de Zamponi, ponen de relieve el estímulo, burgués, de mejorar, de cambiar y conseguir un mundo y un estado personal mejor, incluso si para eso tienen que pasar por la dolorosa, ridícula y vejatoria investidura. Algo de locura hay en todos ellos, y, desde luego, en la escena, pero también algo de la creencia en la utopía de una sociedad mejor. Como tantas veces, utilizar la sátira para contrarrestar un fenómeno no hace sino darle carta de naturaleza y despertar en el lector una curiosidad por aquello que supuestamente se veja. 
El relato es además una versión burlesca y satírica de las novelas de iniciación y aprendizaje, y, sobre todo, una novela de tesis, que se sirve de tres modelos narrativos para exponerla y desarrollarla: narración satírica, sermón y relato bizantino. La tesis es que el liberalismo acaba con la España monárquica y católica; ese liberalismo es, a lo largo del relato, identificado con lo que llama «nueva ilustración», o sea, la «filosofía liberal». Se quiere reflejar que el mal nuevo no lo es, que hay una continuidad entre los intentos reformistas anteriores y éstos.

Desde el principio se muestra una imagen de los liberales del todo negativa, animalizada y viciosa, superficial. Una de las estrategias que Valvidares emplea mejor, y más veces, para acabar con el nuevo orden que propone el abate, es hacerle hablar, en tanto que representante de los liberales; hacerle hablar para que con su propia voz, desde dentro, se desacredite y desarme la nueva ideología, al rebelar su «verdadera» condición, que no es otra sino la del hipócrita:

Nosotros jamás queremos en nuestra hermandad gente muy aguda y clara de entendimiento, porque regularmente es indócil para recibir la buena doctrina y todo lo meten a disputas. Con sus combinaciones escrupulosas, con las consecuencias que deducen de los principios rancios y, lo peor de todo, con lo mucho que se han quebrado los cascos leyendo y meditando toda su vida sin algún fruto, pierden el que pudieran haber cogido en poquísimo tiempo sin el menor trabajo. Estos nunca serán hombres de lucimiento, sino rutineros indecentes, porque su fanatismo y dureza de cerebro los ha desviado de aquella fértil mina donde se cría la piedra filosofal, suspirada de todos los siglos y reservada a nosotros por el hado protector de nuestras luces y, si no, tienda usted la vista por casi todos los liberales que hallaría en Cádiz y otros pueblos, y verá que todos ellos son hombres bonazos, dóciles, vírgenes de cabeza y limpios de corazón (1814: 32).

En el retrato que se hace, la condición de liberal lleva unida inevitablemente la de escritor, de modo que Valvidares aprovecha ese motivo para hacer crítica desde la política de los saberes de los hombres de letras liberales, que, como sus antecesores del siglo XVIII, solo leen la prensa, los diccionarios, las enciclopedias y aquellas obras que tienen poca extensión. Son eruditos, políticos superficiales que quieren trastocarlo todo y, así, dan nombre nuevo a cosas viejas, porque nada debe quedar igual a como estaba, porque sólo parece que les importa la apariencia de las cosas (y la suya propia), lo que manifiesta su condición irreflexiva. También que se encontraban ante un tiempo y una realidad nuevos, que había que nombrar de nuevo modo. Pero sobre todo Valvidares se detiene en analizar su condición de creadores y manipuladores de la opinión, que en su caso es hipocresía y mentira. Ya se sabe la importancia que desde la segunda mitad 
del siglo XVIII tomó el control de la opinión pública, mediante folletos, periódicos y todo tipo de acciones dirigidas a ello. La razón de atacar, pese a valerse de ella, la libertad de imprenta tiene que ver con esto, evidentemente. Pero si insiste una y otra vez en la condición de escritor de los liberales es porque la ve como algo negativo, pues crea opinión, siembra duda y contribuye a romper los mecanismos de control del pensamiento, y los criterios de autoridad que debían regir. Manifiesta así, una vez más, la relación existente entre la política y la literatura -que no puede ni quiere esquivar-, y cómo los autores, él también, se ponían al servicio de intereses e ideologías. ${ }^{3}$ Entra en contradicción consigo mismo y con el tiempo en que vive, pues concede espacio a la opinión, comprende su importancia, quiere manipularla, pero no acepta que sea controlada por otros que no sean él y los que son como él.

Para exponer su tesis del modo más amplio, pone al día varios modelos narrativos anteriores que habían tenido gran fortuna. Va de lo racional, representado por la narración satírica y el discurso o monólogo políticolegal, a lo emocional, asumido en la narrativa de carácter sentimental que es el relato de tono bizantino en el que se cuentan las desdichas de un «abate enjuto». La crítica de los errores liberales y de sus consecuencias se presenta de este modo en el ámbito social e institucional, tanto como en el personal y privado. Así gana la novela en dramatismo.

Junto al modelo satírico, con mucho diálogo, emplea el monólogo. La segunda parte de la novela la constituye un largo discurso del cura del pueblo que, desde su óptica y utilizando autoridades eclesiásticas y del iusnaturalismo, quiere contrarrestar la narrativa del maestro liberal basada en el mensaje del contrato social de Rousseau (2005). El autor cambia el léxico empleado y las estructuras linguiísticas de la sátira para adecuarse al género del discurso, y olvida también el remedo de las hablas rústicas, que había sido habitual en el registro anterior.

Como en sus otros trabajos literarios, demuestra Fray Ramón gran competencia cultural y amplias lecturas, pues no solo la Biblia y los padres de la Iglesia aparecen en el discurso del cura del pueblo y en otros textos suyos, sino también autores «enemigos» y todo un grupo de pensadores que, en el XVII y en el XVIII, desde el nuevo marco de la modernidad, teorizaron el pensamiento tradicionalista y conservador. Eso, sin desaprovechar los tópicos de los reaccionarios europeos, es decir, sin dejar de apuntar a España como salvadora de Europa y al complot antiespañol, que después

3. Sobre el control de la opinión pública a comienzos del siglo XIX, además del trabajo de Glendinning y otros clásicos, véanse Fernández Sebastián y Chassin (2004), Enciso Recio (2007), y la bibliografía allí reseñada. 
tuvo larga vida. De igual modo, cuestiona la Declaración de derechos humanos, donde se perciben ecos de la lectura de las Reflexiones sobre la Revolución en Francia, de Edmund Burke (2003); mientras vuelve del revés el significado de términos claves de la Ilustración y el Liberalismo, como «luces, filosofía, pacto social, árbol de la libertad» y otros.

Sus ideas son claramente absolutistas, conservadoras y tradicionalistas, y apoyan el carácter divino de la monarquía, así como una visión teocrática del mundo. El cura del pueblo, que le sirve de altavoz, se empeña en negar la doctrina del pacto social y las construcciones sobre el estado de naturaleza $\mathrm{u}$ origen presocial en que se encontraba el hombre en los comienzos de la existencia, cuando, en realidad, todos los pensadores, y desde luego, desde el racionalismo del XVII, utilizaron esa estrategia para proponer una imagen diferente: la del progreso del individuo.

En el fondo, Valvidares trata de explicar la sociabilidad humana y la psicología de los individuos. Traza un mapa antropológico de la sociedad, basándose en iusnaturalistas como Pufendorf, Grocio, Hobbes y también en Bossuet, una de las más importantes fuentes del pensamiento tradicional español (Herrero, 1988: 126).

Para completar su estrategia retórica, Valvidares se vale del relato bizantino, que emplea en la tercera y última parte. Hay desencuentros y encuentros, reconocimientos, pasiones y tristeza, viajes por mar y por tierra, apresamientos, llanto, naturaleza sublime. Todo ello con un lenguaje totalmente distinto de los empleados en las dos partes anteriores y con la imaginería propia de esta narrativa, pero contextualizada en la geografía española y europea y en el tiempo de la Guerra.

Pero, además, Ramón Valvidares y Longo aporta otra novedad. Hasta donde yo sé es uno de los primeros en escribir una novela sobre la Guerra de la Independencia. ${ }^{4}$ No sólo ambientada en ella, sino incorporando también algunas escenas bélicas y alusiones al paso de los ejércitos franceses por España y por Europa, pues uno de los personajes es apresado en España por las tropas napoleónicas y llevado a París y luego a Viena para luchar en sus ejércitos. En este sentido, El liberal de Cádiz sería una novedad, pues lo habitual para ejercer la propaganda antifrancesa era utilizar la poesía y el teatro.

No se encuentra nueva publicación suya hasta 1818 . Se trata de $E l$ Cantar de los cantares de Salomón. Paráfrasis en verso castellano, según el sentido místico, conforme a la exposición de los padres e intérpretes católicos, en el que estaba trabajando al menos desde los años 1806 y 1807, como se constata por las actas de la Real Academia sevillana de Buenas

4. La otra, de 1813, es obra de Pablo Rincón, El héroe y heroínas de Montellano, Valencia, Benito Monfort (Álvarez Barrientos, 2004). 
Letras. Bossuet es el autor que le sirve de guía para distribuir los cánticos (181: XVII), igual que su Política deducida de las propias palabras de la Sagrada Escritura era el eje central en parte de Zamponi.

La actitud siempre peleona de Valvidares le llevó en los años del Trienio a combatir los intentos liberales de abolir los diezmos. Fruto de esa controversia es la Disertación que publicó en 1824 en defensa de los mismos y demostrando que su origen y antigüedad están en un precepto divino. Es trabajo ardoroso en su estilo que se lee bien, por el brío y agilidad con que está escrito, en el que se justifican los graves perjuicios que se seguirían al Estado, a la agricultura y a la religión, como consecuencia de suprimir tal impuesto. Valvidares apoya su postura, tradicional en la Iglesia, y que los diezmos fueron instituidos por Dios y a él le pertenecen, en el pago que Abraham hizo a Melquisedec (Levítico, 27, 30). En realidad, con esta obra desarrolla y autoriza lo que ya había quedado claro en El abate Zamponi, donde también se trata el asunto, pues la abolición de tal impuesto, por considerarlo gravoso a los individuos, se discutía desde tiempo atrás y también había sido objeto de disputa en las Cortes gaditanas.

Por lo expuesto hasta ahora, se habrá deducido que Fray Ramón Valvidares escribe a menudo a la contra. Necesita un estímulo que le haga coger la pluma, y éste suele ser la defensa de algo. Abogar a favor de los diezmos era necesario, pues el impuesto resultaba fundamental para la subsistencia de las órdenes regulares. Según Montolío Hernández (1988; 2001), el liberalismo radical había sentido como una urgencia la reordenación o supresión de impuestos como éste, lo que explica que ya el 21 de julio de 1820 se formulara ante el Congreso de los Diputados una proposición de decreto que dio pie a un debate acerca de la necesidad de una reforma tributaria general. La proposición de los exaltados no tuvo éxito, y hubieron de limitar sus ambiciones a conseguir el decreto de 29 de junio de 1821, que reducía el diezmo a la mitad. De todas formas, en 1821 se suprimía la comunidad jerónima, como otras, aunque volvió a tener vida desde 1823 hasta la desamortización de 1835.

Como se ha visto, Valvidares moría en 1826, pero aún publicaría después de muerto, en 1830, El amigo de los niños. En realidad, su participación en esta obra se limita a añadir algunas fábulas y reflexiones morales en prosa, que van en cuerpo menor al final de cada capítulo, pues este libro de Antoine Sabatier de Castres (1742-1817) había sido traducido y publicado en 1795 por Juan de Escoiquiz. Es un tratado de educación que se publica en 1830 para combatir «la corrupción que por desgracia se ha hecho ya contagiosa en nuestros días, pues así lo exige la fidelidad al Rey y la exacta observancia de los preceptos divinos en obsequio de la sacrosanta Religión que profesamos» (1830: s. p.). 
Se mezclan en El amigo textos doctrinales con fábulas, en la seguridad de que este método es el más a propósito para conseguir una sociedad mejor, pues, en idea muy cara a la Ilustración y al autor, como se vio con la Fábulas, «de la educación depende la dicha de toda la sociedad».

\section{UNA FORMA DE SER MODERNO}

Este escritor conservador, que entiende la escritura como un cometido moral, dentro del cual se dan unas exigencias de cultura y de ética, a las que no se puede renunciar, que se manifiestan en la elección y uso de unos registros lingüísticos y retóricos determinados, rompe con ellos para servirse de los mecanismos, instrumentos y experimentos verbales de los escritores liberales. Esto supone un salto cualitativo, pues no solo va a hacer que entre en su discurso el mundo cultural y político ilustrado y liberal, sino que va a combatirlo con sus mismas armas y utilizando la sátira, prohibida por la Iglesia, las sales gruesas y los recursos de la risa y el humor que no tenían, como formas de la literatura de entretenimiento, aceptación entre los moralistas eclesiásticos; todo lo cual se traduce en un uso ambiguo y alusivo del lenguaje y en un cambio de estrategia, que se justifica en la defensa de la «verdadera doctrina», que está siendo atacada. Cambia, por tanto, el modo de escribir y lo que se entiende por la misma escritura.

En cierto modo, la nueva manera de pensar, el nuevo orden que se quiere imponer, y que se ha ido preparando desde el siglo XVII, impregna las formas antiguas y llega a transformarlas, aunque no siempre de una forma violenta. Esta impregnación no supone aceptar absolutamente el relato que se propone, lo que lleva a que existan, al mismo tiempo, distintas formas de ser moderno, o de aceptar (parte de) lo moderno. Esto implicó problemas de legitimidad y estabilidad social, y problemas de comprensión, pues no había una idea clara, ni compartida por extensas masas de la población, acerca del significado de conceptos esenciales como soberanía nacional, liberalismo, etc. ${ }^{5}$

En esta situación, Fray Ramón y otros defienden su imaginario social del nuevo que se les propone, y emplean su mismo lenguaje para dar la vuelta a las propuestas. Incluso Valvidares hablará de «ilustrados superficiales» que son seducidos y engañados, dando a entender que existen

5. La soberanía popular, al igual que la nación moderna, era una idea abstracta para quienes, como los ilustrados, habían aprendido a creer en la monarquía y en la Iglesia, una novedad combatida con vehemencia por los absolutistas, como si de otra aportación revolucionaria francesa se tratara (Fraser, 2006: 315). 
otros ilustrados «buenos» que no se dejan engañar por los cantos de sirena de la modernidad mal entendida. Como sucede a menudo con muchos conservadores que observan los cambios que se operan en la realidad, es capaz de ver lo que va a suceder, pero sobre todo, o solo, de predecir lo negativo.

Al no considerarlo como un absoluto reaccionario, cabría la posibilidad de calificarlo de antimoderno, según la nueva nomenclatura y definición de Antoine Compagnon (2007). Sería, así, un contrarrevolucionario que desconfía de la modernidad, alguien en conflicto con ella. Valvidares es un antimoderno al que perturba la libertad porque pone en duda sus convicciones antiguo régimen; que se defiende, cada vez con más nostalgia de un mundo que ve perdido, de los ataques que sufre; que entiende la libertad como un dispositivo capaz de desestabilizar la vida pública y la privada. No cabe duda, desde luego, de que, al entrar en conflicto con un mundo referencial nuevo, sus objeciones, sus estrategias y argumentos adquieren un valor y un sentido distintos de los que tuvieron antes y, de esta forma, son modernos, pues no le queda más remedio que moverse en ese nuevo espacio y actualizarse. Valvidares sería un hombre de la retaguardia, en el sentido que señaló Roland Barthes (2002: 1038): «ser de vanguardia significa saber lo que está muerto; ser de retaguardia significa amarlo todavía». En él se percibe esta melancolía restauradora casi desde sus primeros trabajos, en los que es más fuerte la belicosidad y la urgencia defensiva.

Consideraba que la Revolución Francesa no había conseguido los resultados deseados: no habían disminuido ni la maldad, ni la injusticia. De modo que continuar por esa línea revolucionaria sólo podía agravar una situación ya mala, además de ser un despropósito. En sus trabajos, a pesar de lo concreto de su motivación, intentó hacer un análisis de la situación histórica y diagnosticar las razones del fracaso de la Revolución, en el fondo, del fracaso de la Ilustración, en tanto que proceso inacabado o traicionado, y de lo insensato que era hollar ese camino, confiando en los liberales.

Como otros, pensaba en el hombre en términos de sumisión, no de igualdad; por lo tanto, defendió la monarquía como la mejor forma de sociabilidad, como la estructura que consolidaba el modo de relación entre los hombres, que son súbditos o vasallos. La monarquía, además, garantizaba la continuidad y la legalidad, pues preservaba la tradición y los valores heredados. La Revolución Francesa y sus consecuencias, entre las que comprendía la invasión napoleónica y el liberalismo, le ayudaron a hacer de su crítica y reacción a las propuestas nuevas un discurso nacionalista, basado en valores morales y en el respeto a las antiguas estructuras, a una 
tradición, que era herencia y legado, y se quería fuera respuesta a las cuestiones que planteaba la nueva sociedad en su conflictiva relación con el pasado y el presente. Frente a los que quisieron levantar una realidad sobre el sistema constitucional, Valvidares optó por el mito historicista del valor del pasado como respuesta a los desafíos contemporáneos. Y a intentar demostrar su validez dedicó su tiempo y su pluma. 


\section{BIBLIOGRAFÍA}

\section{A) De Ramón Valvidares}

VAlVIDARes, Fray Ramón. 1797. Descripción poética. La terrible inundación que molestó a Sevilla en los días 26, 27 y principalmente en la desgraciada noche del 28 de diciembre del año de 1796. Compuesta por el P.... del Orden de San Jerónimo. Danla a luz unos amigos del autor, Sevilla, Hijos de Hidalgo y González de la Bonilla.

- 1807. Sermón moral que en memoria del terremoto acaecido en la ciudad de Sevilla en el año de 1755, y para celebrar la festividad de Todos los Santos, dijo en su Iglesia Catedral el día primero de noviembre, a presencia de ambos Cabildos, el P..., del Orden de San Jerónimo, individuo de la Real Academia Literaria de dicha ciudad, Sevilla (no localizado).

-. [1808a]. La Victoria. Oda al Excmo. Sr. Don Francisco Xavier Castaños, General en Jefe de los Ejércitos de Andalucía, por la batalla ganada a las armas francesas sobre los campos de Andujar y Bailén el día 20 de julio de 1808. F. R. V., Sevilla, Imprenta de las herederas de D. José Padrino.

- 1808b. El desengaño. Discurso histórico político y legal sobre la falsa política de Napoleón I, emperador de los franceses y rey de Italia, etc. Por F. R. V. Sevilla, Imp. de la calle de la Mar.

—. 1811. Fábulas satíricas, políticas y morales sobre el actual estado de la Europa. Por el P..., del Orden de San Jerónimo de la Congregación de España, Profeso del Monasterio de Bornos y académico de la Real Academia de Bellas Letras de Sevilla, s.l., s.i.

- 1813. La Iberiada. Poema épico a la gloriosa defensa de Zaragoza, bloqueada por los franceses desde 14 de junio hasta 15 de agosto de 1808, y desde 27 de noviembre de este año hasta 21 de febrero de 1809, Por el P. Fr...., monje del orden de San Jerónimo del monasterio de Bornos e individuo de la Real Academia de Buenas Letras de Sevilla, Cádiz, Vicente Lema y D. Diego García Campoy (primer tomo); D. Diego García Campoy (segundo tomo).

—. 1814. El liberal en Cádiz, o aventuras del abate Zamponi. Fábula épica para remedio de locos y preservativo de cuerdos. Por F. R. V., Sevilla, Imprenta del Correo Político Mercantil, a cargo de Manuel Valvidares.

- . [1816]. Sermón panegírico que en la anual memoria y solemne festividad, que consagra la ciudad de Sevilla al Todopoderoso, por su feliz restauración y conquista hecha del Yugo Mahometano en el año de 
1248 por don Fernando III, dijo en su iglesia catedral el 23 de noviembre de 1816..., del orden de San Jerónimo, profeso del monasterio de Bornos, y Prior del de la ciudad de Écija, Calificador del Consejo de la Suprema y General Inquisición de estos reinos, Teólogo Consultor y Examinador sinodal de la Nuciatura Apostólica, Académico de la Real Academia Literaria de esta ciudad y Examinador Sinodal del Obispado de Córdoba, etc., Sevilla, Imprenta de Padrino.

- 1818. El Cantar de los cantares de Salomón. Paráfrasis en verso castellano, según el sentido místico, conforme a la exposición de los padres e intérpretes católicos. Su autor el P. Mro., ex prior..., del orden monástico de San Jerónimo, profeso del Monasterio de Bornos, Calificador del Consejo de la Suprema y General Inquisición, Teólogo-Consultor de la Nunciatura Apostólica, Académico de la Real Academia literaria de Sevilla, Examinador Sinodal de su Arzobispado y del obispado de Córdoba, Sevilla, Imprenta Real y Mayor.

—. 1819. Relación circunstanciada de las solemnes exequias con que la Ilustre y Noble Ciudad de Carmona honró la memoria de Nuestra Reina y Señora Doña María Isabel de Braganza, en los días 21 y 22 de enero de 1819, con la oración fúnebre que se dijo en ellas, Sevilla, Imprenta Real y Mayor.

- 1820. Afectos devotos para ejercicio y consuelo de las almas espirituales, sacados de los salmos del Real Profeta David. Por el Sr. Don Lorenzo Delgado, presbítero, caballero de la Real y Distinguida Orden española de Carlos III, Predicador de Cámara de S. M. Examinador Sinodal de este Arzobispado y Obispado de Jaén, socio de erudición de la Medicina y otras ciencias de esta ciudad. Y traducido a nuestro metro castellano por el D. M. Ex Prior..., del orden monástico de San Jerónimo, Sevilla, Padrino.

—. 1824. Disertación teólogo- canónica sobre el origen, antigüedad y precepto de los diezmos, y sobre los gravísimos perjuicios que causaría su abolición a la Religión, al Estado y a la Agricultura. Obra trabajada por los años de 1820 para impugnar el discurso que el diputado don Sebastián de Ochoa pronunció en las Cortes de dicho año contra la antigüedad y firmeza de este divino precepto. Su autor...del orden monástico de San Jerónimo, profeso del Monasterio de Bornos, Calificador del Consejo de la Suprema y General Inquisición, Teólogo- Consultor de la Nunciatura Apostólica, Académico de la Real Academia literaria de Sevilla, Examinador Sinodal de su Arzobispado y del obispado de Córdoba Madrid, Aguado.

-. 1825. Apología teológico- canónica de los diezmos, donde por un enlace no interrumpido de todos los siglos, desde la ley escrita, hasta el 
Concilio de Trento, se prueba que ellos son de precepto divino, dado por Dios en ambos Testamentos y definido por la Iglesia católica en dos concilios generales y en otros muchos nacionales... Por..., autor de La Iberiada, Madrid (no localizado. Aguilar Piñal, 1995, VIII).

- 1825. La Iberiada. Poema épico a la gloriosa defensa de Zaragoza, bloqueada por los franceses desde 14 de junio hasta 15 de agosto de 1808, y desde 27 de noviembre de este año hasta 21 de febrero de 1809, Madrid. Imp. de E. Aguado, 2 vols., segunda edición.

- 1830. El amigo de los niños, escrito en francés por el abate Sabatier, traducido por don Juan de Escoiquiz, y adicionado por el M. R. P. M. Fray ..., Calificador del Consejo de la Suprema, Examinador sinodal del Arzobispado de Sevilla y Teólogo Consultor de la Nunciatura Apostólica, Madrid, Imprenta de D. Eusebio Aguado.

B) Secundaria

Aguilar Piñal, Francisco, La Real Academia sevillana de Buenas Letras en el siglo XVIII, Sevilla, Colegio Oficial de Aparejadores y Arquitectos Técnicos, 2001.

Alcalá Galiano, Antonio, Literatura española del siglo XIX, Madrid, Alianza Editorial, 1969.

Almuiña, Celso, «Opinión pública y revolución liberal», Cuadernos de Historia Contemporánea, 24, 2002, pp. 81-103.

Barthes, Roland, «Réponses», en Oeuvres complétes, III, ed. Eric Marty, Paris, Éditions du Seuil, 2002.

Burke, Edmund, Reflexiones sobre la Revolución en Francia, ed. Carlos Mellizo, Madrid, Alianza Editorial, 2003.

Compagnon, Antoine, Los antimodernos. Barcelona, Acantilado, 2007.

Enciso Recio, Luis Miguel, «Los mensajes de la opinión pública y la propaganda en la España moderna», en AA. VV., Propaganda y opinión pública en la Historia, Valladolid, Universidad, 2007, pp. 49-90.

Fernández De Moratín, Leandro, Apuntes de D...sobre el plan y algunas frases de La Iberiada, BN, ms. 12963 (26) [1813].

Fernández Sebastián, Javier y Chassin, Joëlle (coords.), L'avènement de l'opinion publique. Europe et Amérique XVIII - XIX ${ }^{e}$ siècles, Paris, L'Harmatan, 2004.

Ferraz Martínez, Antonio, «Una novela olvidada de 1814 (El liberal en Cádiz o aventuras del abate Zamponi)», en Comentarios de textos literarios Hispánicos. Homenaje a Miguel Ángel Garrido, eds. Esteban Torre y José Luis García Barrientos, Madrid, Síntesis, 1997, pp. 129-165. 
FrASER, Ronald, La maldita guerra de España. Historia social de la Guerra de la Independencia, 1808-1814, Barcelona, Crítica, 2006.

Freire López, Ana $\mathrm{M}^{\mathrm{a}}$, «La fábula como forma de la sátira política en la España de principios del siglo XIX», en Ideas y movimientos clandestinos. De la Ilustración al Romanticismo: Cádiz, América y Europa ante la modernidad, 1750-1850, Cádiz, Universidad, 1988, pp. 303-315.

- Poesía popular durante la Guerra de la Independencia Española (1808-1814). Índice de las composiciones publicadas en la prensa periódica y en folletos de la Colección Documental del Fraile, London, Grant \& Cutler, 1993.

Gómez Imaz, Manuel, Los periódicos durante la Guerra de la Independencia (1808-1814), Madrid, Tipografía de Archivos, 1910.

Herrero, Javier, Los orígenes del pensamiento reaccionario español, Madrid, Alianza Editorial, 1988.

Matute y Gaviria, Justino, Hijos de Sevilla señalados en Santidad, Letras, Armas, Artes o Dignidad, anotados y corregidos por la Redacción del Archivo Hispalense, II, Sevilla, Oficina de El Orden, 1887.

Méndez Bejarano, Mario, Diccionario de escritores, maestros y oradores naturales de Sevilla y su actual provincia, III, Sevilla, Tipografía Gironés, 1925.

Montolío Hernández, Ricardo, «El medio diezmo. Un episodio en la reforma eclesiástica del trienio liberal (1820-23)», Hispania Nova, 1998- 2000, 1.

— «La reforma de la dotación del culto en el Trieno Liberal (1820-1823)», Espacio, Tiempo y Forma, Historia Contemporánea, 14, 2001, pp. 33-54.

Palacios Fernández, Emilio y Romero Ferrer, Alberto, «Teatro y política (1789- 1833): entre la Revolución Francesa y el silencio», en $S e$ hicieron literatos para ser políticos. Cultura y política en la España de Carlos IV y Fernando VII, ed. Joaquín Álvarez Barrientos, Madrid, Biblioteca Nueva, 2004, pp. 185-242.

Rincón, Pablo. 1813 El héroe y heroínas de Montellano, Valencia, Benito Monfort.

Romero Ferrer, Alberto. 2004. «Poesía y cambio político (1789-1833)», en Se hicieron literatos para ser políticos. Cultura y política en la España de Carlos IV y Fernando VII, ed. Joaquín Álvarez Barrientos, Madrid, Biblioteca Nueva, pp. 167-184.

Rousseau, Jean- Jacques, Del contrato social. Sobre las ciencias y las artes. Sobre el origen y fundamentos de la desigualdad entre los hombres, ed. Mauro Armiño, Madrid, Alianza Editorial, 2005. 